\title{
The Influence of Vermicomposting Technology on Solubility of Eppawala Rock Phosphate
}

\author{
S.H.S. Senarathne and S.S. Udumann
}

\begin{abstract}
The application of Eppawala Rock Phosphate (ERP) could be an economic alternative to the use of imported phosphorus fertilizer for certain annual as well as perennial crops like coconut in acid soils. But, its low solubility limits direct application. For Vermicomposting technology, which is a biodegradation process of plant and animal waste materials through earthworms, has been-tested for increasing the solubility of ERP. Fresh Gliricidia leaves, fresh cow dung and grasses were mixed 1:2:1 ratio as the basic composting mixture and ERP was mixed at the ratio of $10 \%$ and $20 \%$ to the composting materials. Forty numbers of earthworms were added to each of the plastic containers with the composting mixture, having five replicates per treatment.

Addition of ERP in to mixture showed no effect on the multiplication rate of earth worms. The nutrient availability of compost was measured with time and compared with the control $\left(\mathrm{T}_{1}\right)$. Each treatment had the similar amount of nitrogen in the system and that indicates the addition of rock phosphate has a minimal effect or no effect on conversion or losses of available nitrogen. Addition of ERP increased the availability of phosphorus and it was significantly higher in $T_{4}$ and $T_{3}$ than other treatments. Available phosphorus value was significantly increased from $4 \%\left(\mathrm{~T}_{5}\right.$ and $\left.\mathrm{T}_{6}\right)$ to $9 \%$ in $\mathrm{T}_{3}$ and $\mathrm{T}_{4}$ treatments. Total potassium content decreased in all treatments compare with control. Therefore, vermicomposting can be utilized to increase the solubility of ERP while increasing the available phosphorus in the end product.
\end{abstract}

Key words: Vermicompost, Rock Phosphate, solubility and phosphorus

Running title: Solubility of rock phosphate

\section{Introduction}

Imported Rock Phosphate (IRP), Triple Super Phosphate (TSP) and Eppawala Rock Phosphate (ERP) are three major sources of phosphorus fertilizers and widely use in coconut plantations in Sri Lanka. ERP is a locally available source of phosphorus instead of IRP and TSP. TSP is the most dominant phosphorus fertilizer used for short duration crops (Wijewardena, 1994). Local rock phosphate named Eppawala Rock Phosphate is mainly being used for perennial fruit and plantation perennial crops grown in wet zone of Sri Lanka. However, number of research studies conducted in relation to ERP revealed that it cannot match with the P supplying ability of TSP for annual crops and its direct application as a source of $\mathrm{P}$ fertilizer for food crops will not be beneficial (Wijewardena, 1994). Various crop research institutes in Sri Lanka have recommended decrease application of ERP for certain soil and crop conditions as it is an agronomical and economically beneficial alternative to the expensive high concentrated phosphate fertilizers, due to the poor solubility of ERP, it is not used extensively or officially recommended for short term crops (McClellan, 1978). However, small quantities of ERP combined with other soluble phosphate fertilizers are applied to young plantations and other crops (Dinalankara, 1995).

Coconut Research Institute, Lunuwila, Sri Lanka.

Email: shsumith71@yahoo.com 
Vermicomposting is a simple biotechnological process of composting, in which certain species of earthworms are used to enhance the process of waste conversion and produce a better end product (www.vermiculture.com, 2008). It is not an action of earth worms alone but a number of other microorganisms are associated with the processes which have capacities to create and provide necessary nutrients to the crop according to their requirements (Bhawalkar, 1990). This results in numerous types of bacteria and fungi that produce a large number of organic acids like citric, malic, fumaric, succinic, propunic acids and humic substances. The enhancement of ' $P$ ' release from phosphate of phosphate rock by organic acids and more importantly their chelating ability with Calcium $(\mathrm{Ca})$, Iron $(\mathrm{Fe})$ and Aluminium (Al) (Ghani et al., 1994). There is a great potential to release the available ' $\mathrm{P}$ ' by dissolving them in organic acids than the mineral acids. Also, participation of the ' $\mathrm{OH}$ ' groups with carboxyl groups have more evidence to release of ' $\mathrm{P}$ ' from phosphate rocks with their organic acids (Wijewardena, 1994).

Phospho-compost is a new technology developed and used in Sri Lanka to utilize insoluble ERP in crop production. As a results of biological conversion process phosphorcomposts are provided as organic compound. It is the process of treating rock phosphates with organic materials (plant and animal origin) and composting them for enhancing the solubility and the subsequent availability to plants of phosphorus (P) from phosphate rocks (Premaratne and Von Fragstein, 2002). Phospho-composting offers the advantages of using low soluble phosphate rocks and the environmental advantage of safe disposal of organic waste. As an additional benefits application of the phosphor-compost is provided the easiest way of the movement of dissolved ' $\mathrm{P}$ ' to a greater soil depth which provides a larger soil volume for ' $\mathrm{P}$ ' uptake by plants (Premaratne and Von Fragstein, 2002). Also, vermicomposting supplies suitable mineral balance, organic acids and humic substances as a result of biodegradation (Atiyeh et al., 2000). Due to the acidic nature, there may be a possibility to increase solubility of the ERP with integrating vermicomposting process. That condition is used to study the influence of vermicomposting on solubility of ERP. This will enhance the potential availability of phosphorus for short term crops like rice and vegetables. The main objective of this study is to study on the influence of vermicomposting on solubility of ERP.

\section{Materials and methods}

This experiment was carried out at the vermicomposting unit of the Coconut Research Institute, in the Low country Dry Zone of North Western province of Sri Lanka from October 2012 to December 2012. The area is characterized by bi-modal pattern of rain fall with an annual mean precipitation of $1500 \mathrm{~mm}$. Approximately $65 \%$ of the annual rainfall is received from April to August (south west monsoon).

Fresh Gliricidia sepium, green grass (Panicum maximum) leaves were collected and chopped into small pieces and mixed with fresh cow dung separately. The proportion of cow dung and plant residues was 1:2. The mixture was added to black polythene bags (gauge 500); height and diameter of a bag was $60 \mathrm{~cm}$ and $30 \mathrm{~cm}$ respectively. After adding the mixture, 20 worms from selected species (Eisenia foetida) and $200 \mathrm{ml}$ of water was added into each polythene bag and these were kept in the shade house. The weight and length of all 20 worms were measured before introducing to the pots.

The treatments were arranged in Complete Randomized Design with ten replicates. Small holes were made in the polythene bag to remove excess water, although worms could not move through them. This mixture was kept for eight weeks to decompose the materials. Once a week mixture was removed from the pots and mixed well to facilitate aeration. After mixing, $100 \mathrm{ml}$ of water was added into each pot.

\section{Different treatment combinations:}

$\mathrm{T}_{1}$ - $02 \mathrm{~kg}$ of basic composting mixture without worms (control) 
$\mathrm{T}_{2}-02 \mathrm{~kg}$ of basic composting mixture without ERP with worms

$\mathrm{T}_{3}-02 \mathrm{~kg}$ of basic composting mixture with $200 \mathrm{~g}$ of ERP with worms

$\mathrm{T}_{4^{-}} 02 \mathrm{~kg}$ of basic composting mixture with $400 \mathrm{~g}$ of ERP with worms

$\mathrm{T}_{5^{-}} 02 \mathrm{~kg}$ of basic composting mixture with $200 \mathrm{~g}$ of ERP without worms

$\mathrm{T}_{6}-02 \mathrm{~kg}$ of basic composting mixture with $400 \mathrm{~g}$ of ERP without worms.

\section{Growth measurement of worms}

Initial weight, length and numbers of worms were determined and counted as the first growth measurement before introducing to the mixtures. Thereafter, weight, length and number of worms were measured and counted at monthly intervals.

\section{Nutrient analysis of vermicompost}

Prepared vermicompost was sieved by a $2 \mathrm{~mm}$ sieve, air dried and $100 \mathrm{~g}$ samples were obtained from each treatment and replicate. The following were measured in the samples. The $\mathrm{pH}$ of samples was recorded by a digital $\mathrm{pH}$ meter. The organic matter content and organic carbon of the samples were measured by Walkey-Black method (Walkley and Black, 1934); N was estimated by the Kjeldahl method (Jackson, 1973), and $P$ and $K$ contents of the samples were analyzed by calorimetric method (Anderson and Ingram, 1993) and flame photometric method (Simard, 1993), respectively.

\section{Statistical analysis}

Data analysis of the above experiment was conducted using an Analysis of Variance (ANOVA) with the Statistical software and the significance of the differences between means was tested using Least Significant Differences (LSD) at $\mathrm{P}=0.05$ (SAS Institute 1999).

\section{Results and discussion}

Effect of treatments on worm population development during the vermicomposting process

The difference of the worm population growth in different composting substrate were not statistically significant $(\mathrm{P}=0.05)$. During the experimental period, the highest worm development percentages were observed in $\left(\mathrm{T}_{3}\right)$ and $\left(\mathrm{T}_{4}\right)$. However, numbers of earthworms increased rapidly after $4^{\text {th }}$ week in worm applied treatments. This result also indicates that addition of ERP had no or minimal effect on multiplication of earthworms. However, the increase in the number of worms was noted in different composting substrates during the vermicomposting process, which could be due to the substrate quality, especially chemical compounds (Reinecke et al., 1992). Some plants species secrete some toxic compounds to the environment and these are poisonous to living organisms (Atiyeh et al., 2000).

\section{Effect of different treatments on temperature during the composting process}

There are no significant effects of treatments on initial and final temperature of the composting mixture (Figure 2). The finding showed temperature requirement for optimal results is $20^{\circ} \mathrm{C}-30^{\circ} \mathrm{C}$. However, survival of earthworms was observed even at lower temperatures and up to $48^{\circ} \mathrm{C}$. Obviously with little provision of hade temperature within worm feed substrate can be reduced. It is desirable, that substrate should not be tightly packed in containers (Atiyeh et al., 2000).

\section{Effect of different treatments on $\mathrm{pH}$ value of compost}

The $\mathrm{pH}$ variation was not significantly different between treatments at initial stage (Figure 3). However, $\mathrm{pH}$ values of final products were significantly low in all the worms apply treatments and the values were neutral around 7. The initial decrease in the substrate $\mathrm{pH}$ can be 


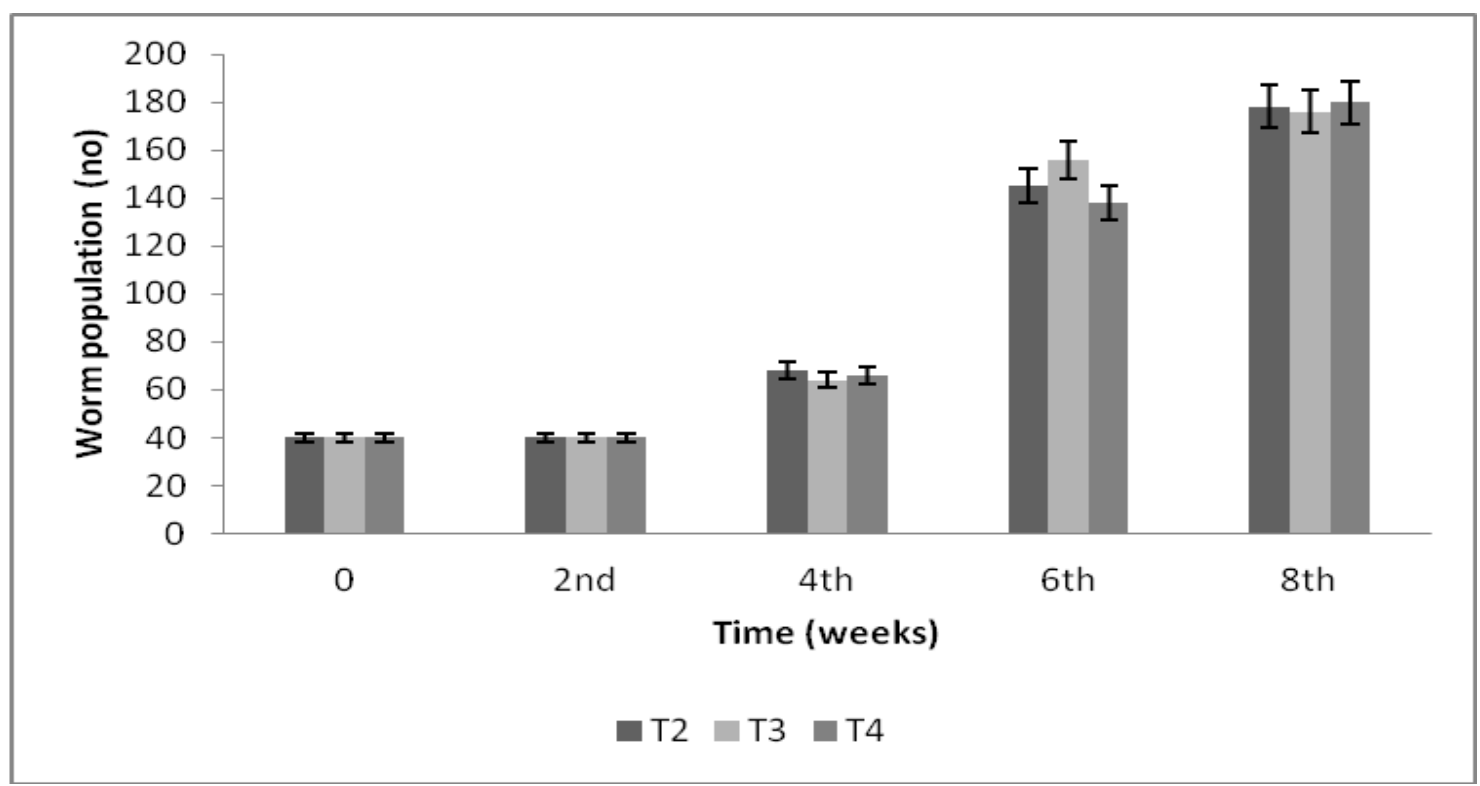

(In each column, values with the same letter are not significantly different at $p<0.05$ (LSD), Vertical bars indicate + SE of the mean)

Figure 1. Effect of different testaments on worm population growth

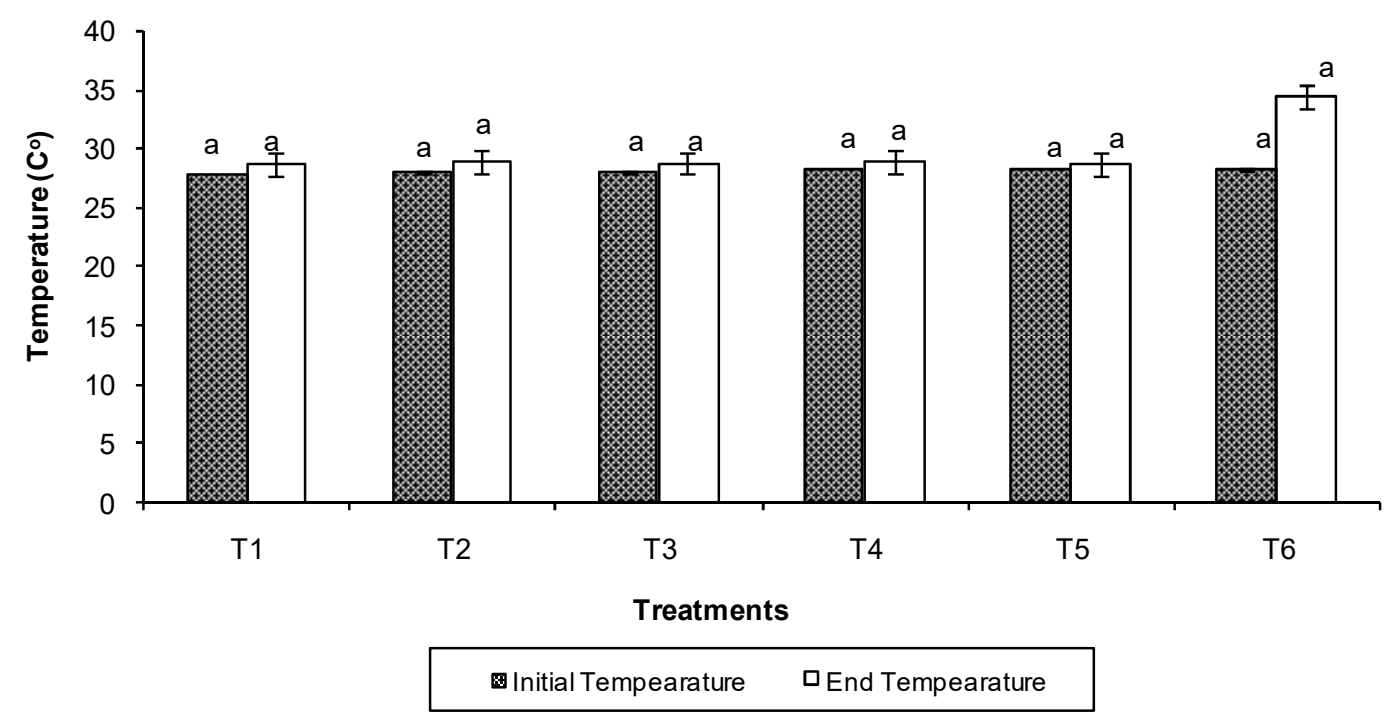

(In each column, values with the same letter are not significantly different at $p<0.05$ (LSD) Vertical bars indicate \pm SE of the mean)

Figure 2. Effect of different treatments on final temperature 


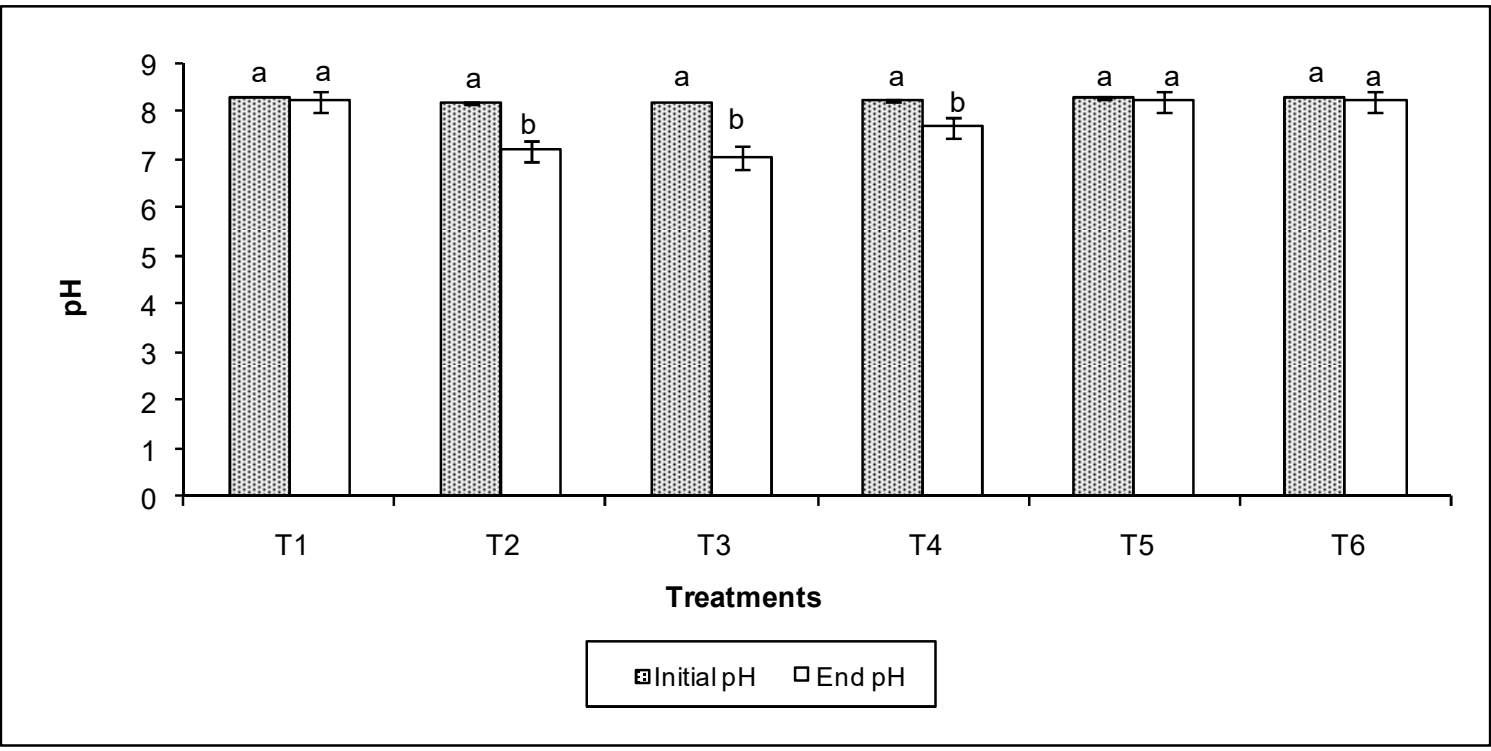

(In each column, values with the same letter are not significantly different at $p<0.05$ (LSD) Vertical bars indicate + SE of the mean)

Figure 3. Effect of different treatments on pH

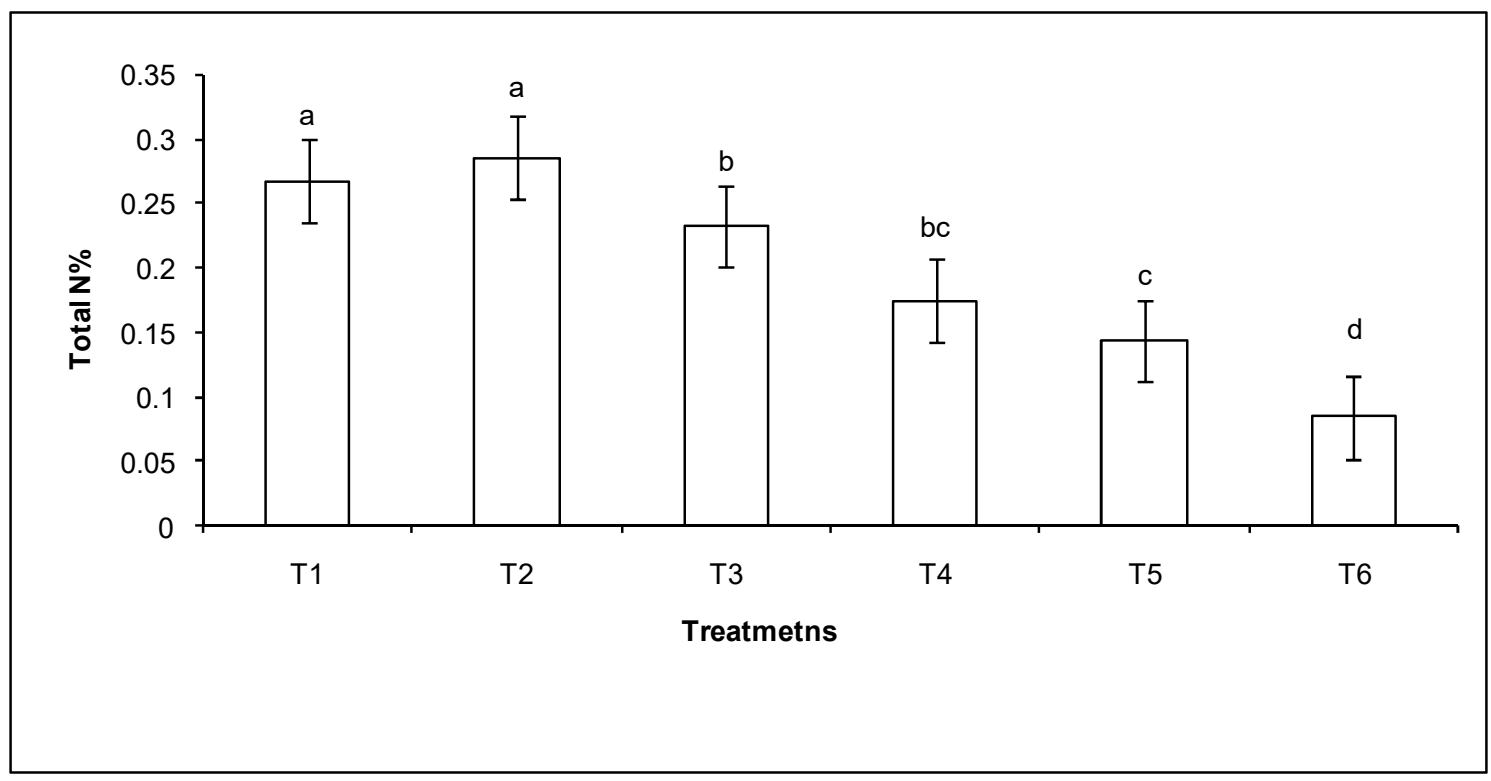

(In each column, values with the same letter are not significantly different at $p<0.05$ (LSD) Vertical bars indicate + SE of the mean)

Figure 4. Effect of different treatments on $N \%$ of compost 
attributed to the fact that initially microbes participate in the degradation representing aerobic metabolism. According to Ghani et al., (1994) intensive microbial activities occurred during the decomposition of organic materials. This results in development of numerous types of bacterial, fungi and earthworms. Subsequently the conversion of complex compounds into simpler forms during the microbial action causes formation of weak acids, which become predominant in comparison to formation of basic compounds. The net effects of more weak acids and less base formation results as a decrease in $\mathrm{pH}$ at a slower rate (Singh et al., 1982). $\mathrm{CO}_{2}$ and organic acids produced during microbial metabolism probably decrease the $\mathrm{pH}$ during composting (Singh et al., 1982). The near neutral $\mathrm{pH}$ of vermicompost may be attributed by the secretion of $\mathrm{NH}_{4}{ }^{+}$ions that reduce the pool of $\mathrm{H}^{+}$ ions (Tripathi and Bhardwaj, 2004) and the activity of calciferous glands in earthworms containing carbonic anhydrase that catalyze the fixation of $\mathrm{CO}_{2}$ as $\mathrm{CaCO}_{3}$, thereby preventing the development of low $\mathrm{pH}$ values (Kale et al., 1982). The increase in $\mathrm{pH}$ during the process is probably due to the degradation of short chain fatty acids and ammonification of organic $\mathrm{N}$ (Guoxue et al., 2001). Suthar (2007) found an increased $\mathrm{pH}$ at the end of the composting process, which was attributed to progressive utilization of organic acids and increase in mineral constituents of waste. However, the initial $\mathrm{pH}$ of the raw materials has a robust correlation with the ability of the waste conversion into vermicompost, where a lower $\mathrm{pH}$ resulted in faster conversion (Hasnah and Hasnuri, 2008).

\section{Effect of different treatments on total $N$ content of vermicompost}

The total nitrogen percentage was significantly different among treatments and the highest value was observed in $\mathrm{T}_{2}(0.2858 \%)$ treatment. The minimum total $\mathrm{N}$ content was observed in $\mathrm{T}_{5}(0.144 \%)$ and $\mathrm{T}_{6}(0.084 \%)$ treatments.

The enhancement of $\mathrm{N}$ in vermicompost was probably due to mineralization of the organic matter containing proteins (Bansal and
Kapoor, 2000) and conversion of ammonium nitrogen into nitrate (Suthar and Singh, 2008). However, earthworms can boost the nitrogen levels of the substrate during digestion in their guts adding their nitrogenous excretory products, mucus, body fluid, enzymes and even though the decaying dead tissues of worms (Suthar, 2007). According to the (Singh et al., 1982) found that relatively high content of $\mathrm{N}$ in the rock phosphate added compost compared to the control without rock phosphate. In a similar study Singh and Yadau (1986) also observed higher content of total nitrogen in the compost made with rock phosphate and claims that reduced nitrogen losses may be attributed to formation of phospho proteins which are less prone to volatilization. However, in general one of the objectives of the addition of mineral additives such as rock phosphate to vermicomposting materials is to improve the quality of the vermicompost by reducing nitrogen losses.

\section{Effect of different treatments on $K$ content of vermicompost}

There was a significant difference among treatments on $\mathrm{K}$ content of final compost product. The highest total $\mathrm{K}$ percentage was observed in $\mathrm{T}_{1}(1.706 \%)$ while second highest level $(1.372 \%)$ was recorded in $\mathrm{T}_{2}$. The lowest $\mathrm{K}$ percentage was observed in $\mathrm{T}_{6} \quad(0.363 \%)$ (Figure 5). The total $\mathrm{K}$ content of $\mathrm{T}_{3}(0.742 \%)$ and $\mathrm{T}_{4}(0.659)$ were not significantly different. The increase in $\mathrm{K}$ content of the vermicompost in relation to that of the compost substrate was probably because of physical decomposition of organic matter of waste due to biological grinding during passage through the gut, coupled with enzymatic activity in worm's gut, which may have caused it increase (Rao et al., 1996). The microorganisms present in the worms gut probably converted insoluble $\mathrm{K}$ into a soluble form by producing the microbial enzymes (Kaviraj and Sharma, 2003).

\section{Effect of different treatments on available $P$ content of vermicompost}

The available phosphorus percentage was significantly different among treatments and the highest value was observed in $\mathrm{T}_{4}(9.24 \%)$ 


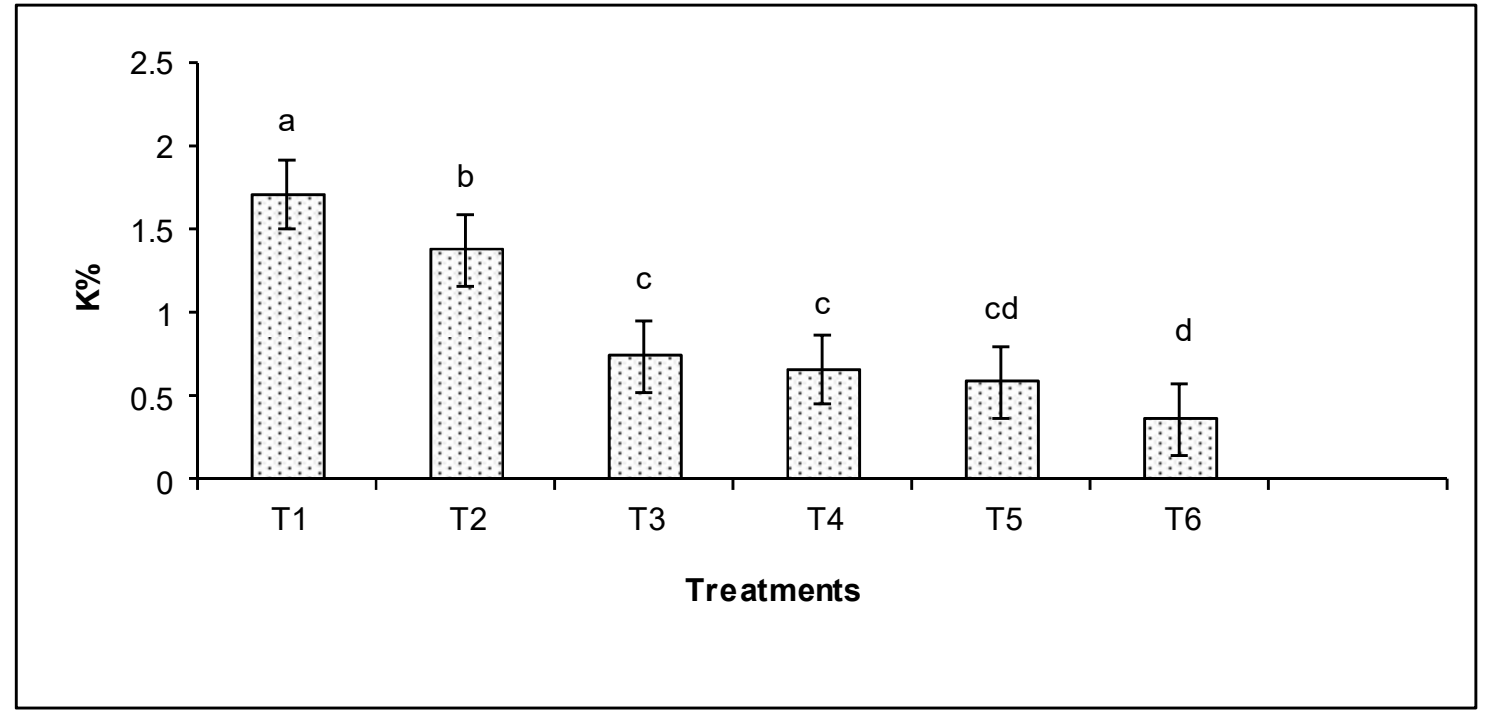

(In each column, values with the same letter are not significantly different at $p<0.05$ (LSD) Vertical bars indicate + SE of the mean)

Figure 5. Effect of different treatments on $\mathrm{K} \%$ of compost

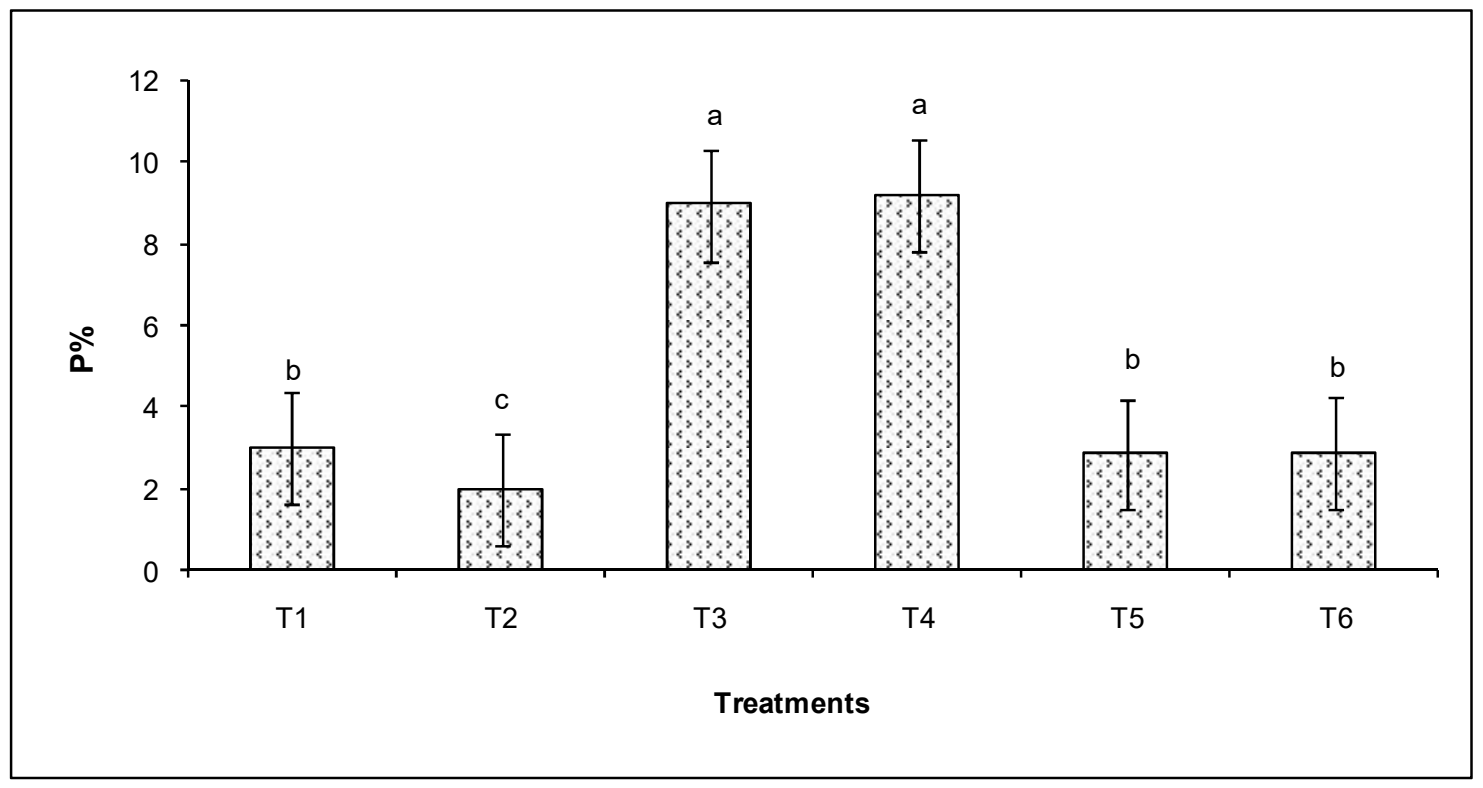

(In each column, values with the same letter are not significantly different at $p<0.05$ (LSD) Vertical bars indicate + SE of the mean)

Figure 6. Effect of different treatments on available $P$ content of vermicompost 
treatment and second highest (8.56\%) level was recorded in $\mathrm{T}_{3} \quad(\mathrm{P}<0.05)$. There was a no significant difference between $T_{3}$ and $T_{4}$ treatments by considering the available phosphorus. The available phosphorus percentage in $T_{1}, T_{2}, T_{5}$ and $T_{6}$ were also significantly different from each other. The lowest available phosphorus content was observed in $T_{1}$ and $T_{2}$ treatments (Figure 6).

According to the findings of Chien (1992), the available phosphorus content in rock phosphate is very low being about 3-5\%. During the process of vericomposting carbonic acids are produced and it is responsible for the solubalization of tri calcium phosphate in the rock phosphate and liberation of phosphorus into the solution. Confirming the results of Rao et al., (1996) the highest relative increase of citric acid soluble $\mathrm{P}_{2} \mathrm{O}_{5}$ was found in the treatment $5 \%$ rock phosphate and beyond that addition of rock phosphate tends to reduce the relative solubility. The finding showed (Singh et al., 1982) much of the phosphorus in the soils is bound to organic matter in forms that are unavailable to plants.

It is now well established that passage through the gut of the some lumbricid earthworms results in some of this phosphorus being converted to forms that are plant available. According to the Singh and Ambeger (1991) claimed that humic substances especially fulvic acids absorbed a significant amount of calcium and release hydrogen ion which help in rock phosphate soulbalization. At the same humic substances produced during the decomposition of organic matter may also re-precipitated both solubalized phosphorus and calcium by complex building and creating a sink in the system for further dissolution of rock phosphate.

Most of the soluble phosphor released during decomposition is utilized by micro flora and is re-fixed due to presence of soluble calcium in the system. The plants can absorb the re-fixed phosphorus (Singh et al., 1982).

\section{Conclusion}

Vermicomposting technology can be utilized to increase the solubility of Eppawala Rock Phosphate while and increase the available phosphorus in the end product. Addition of ERP into compost mixture had no effect on multiplication rate of earth worms.

\section{References}

Anderson, J.M. and Ingram, J.S.I. 1993. Tropical Soil Biology and Fertility. A Handbook of Methods $2^{\text {nd }}$ ed. Wallingford, UK: CABI Publishing, pp 221.

Atiyeh, R.M., Lee, S., Edwards, C.A., Subler, S. and Metzger, J.D. 2000. Earthworm processed organic wastes as components of horticulture potting media for growing marigold and vegetable seedlings. Compost Science and Utilization, 8: 215223.

Baker, G.H. 1983. Distribution, abundance and species association of earth worms (Lumbricidae) in a reclaimed in Ireland, Holarc. Ecol.6: 74-80.

Bansal, S. and Kapoor, K.K. 2000. Vermicomposting of crop residues and cattle dung with Eisenia foetida. Bio resource Technology, 73: 95-98.

Bhawalkar, U.S. 1990. Bio conservation of wastes into resources, $4^{\text {th }}$ International Symposium on Earth Worms Ecology, June 10-14, 1990 Avignon, France.

Chien, S.H. 1992. Reactions of phosphate rock with Acid Soils of the humid tropics. In. Workshop on phosphate sources for Acid Soils in the Humid Tropics of Asia. RRIM and MSSS, Kuala Lumpur: 18-29.

Dinalankara, D.M.S.K. 1995. Eppawala Phosphate Deposit of Sri Lanka Present status. Soil Biology and Biochemistry 26 (1), 153-163.

Ghani, A., Rajan, S.S.S. and Lee, A. 1994. Enhancement of phosphate solubility through biological process. Soil Biology and Biochemistry, 26(1), 127-136.

Guoxue Li, Zhang, F., Sun Y, Wong, J.W.C. and Fang, M. 2001. Chemical evaluation of sewage composting as mature indicator for composting process. Water Air Soil Sludge Pollution, 132: 333-345.

Hasnah, M.J. and Hassan, H.M. 2008. Waste conversion to vermicast by Eisenia foetida 
given four types of organic substrates in the natural Malaysian environmental conditions, Journal of Bioscience, 19: 6372.

Jackson, M.L. 1973. Soil Chemical Analysis $\left(1^{\text {st }}\right.$ Ed), Prentice Hall of India Private Limited, New Delhi, 111-204.

Kale, R.D., Bano, K. and Krishnamoorthy, R.V. 1982. Potential of Perionyx excavatus for utilization of organic wastes. Pedobiologia, 23: 419-425.

Kaviraj, S. and Sharma, S. 2003. Municipal solid waste management through vermicomposting employing exotic and local species of earthworms. Bio resource Technology. 90: 169-173.

Lee, K.E. 1985. Earthworms: Their Ecology and Relationships with Soils and Land Use, Academic Press, London, 411.

Mc Clellan, G.H. 1978. Mineralogy and reactivity of phosphate rock for direct application. Haifa, Isreal, March 20-23, 1978. IFDC publication, IFDC, Muscle Shoals, Alabama, 35660, USA: pp 57-81.

Premarathne, K.P. and Von Fragstein, P. 2002. Influence of straw -composting on the solubility of rock phosphate. Sri Lankan J. Agric. Sci, vol 39: 102-115.

Rao, S., Rao, A.S. and Takkar, P.N. 1996. Changes in different forms of $\mathrm{K}$ under earthworm activity. National Seminar on Organic Farming and Sustainable Agriculture, India, 9-11.

Reinecke, A.J., Viljoen, S.A. and Saayman, R.J. 1992. The suitability of Eudrilus eugeniae, Perionyx excavatus and Eisenia fetida (Oligochaeta) for vermicomposting in southern Africa in terms of their temperature requirements. Soil Biology and Biochemistry, 24: 1295-1307.

[SAS] Statistical Analysis Systems, 1999. SAS 1, STAT Users Guide, Release, 7.00 Cary, NC: Statistical Analysis Systems Institute, 1028.

Simard, R.R. 1993. Ammonium acetate extractable elements. In: Martin R, Carter
S (Eds) Soil sampling and methods of analysis, Lewis Publisher, Florida, USA, 39-43.

Singh, C.P., Mishra, M.M. and Kapoor, K.K. 1982. Solubalization of insoluble phosphate by mesophilic fungi. Revued' Ecologie et de la Biologie du Sol. 19:1725 .

Singh, C.P. and Amberger, A. 1991. Solubalization and availability of phosphorus during decomposition of rock phosphate enriched straw and urine, Biological Agriculture and Horticulture 7, 261-269.

Singh, R.D. and Yadav, D.V. 1986. Evaluation of low grade rock phosphate composted with some agricultural wastes for use in a crop rotation, Agric Wastes, 18(1): 73-79. (Filed Crop Abst. 10(2): 623-1987).

Suthar, S. 2007. Nutrient changes and biodynamics of epigeic earthworm Perionyx excavatus (Perrier) during recycling of some agriculture wastes. Bioresource Technology, 98: 1608-1614.

Suthar, S. and Singh, S. 2008. Vermicomposting of domestic waste by using two epigeic earthworms (Perionyx excavatus and Perionyx sansibaricus). International Journal of Environment Science and Technology, 5: 99-106.

Tripathi, G. and Bhardwaj, P. 2004. Comparative studies on biomass production, life cycles and composting efficiency of Eisenia fetida (Savigny) and Lampito mauritii (Kinberg). Bioresource Technology, 92: 275-283

Walkley, A. and Black, I.A. 1934. An examination of the Degtjareff method for determining soil organic matter and prepared modification of the chronic acid titration method. Soil Science, 34: 29-38.

Wijewardana, J.D.H. 1994. The effect of poultry manure and its chemical constituents on rock phosphate solubility. $\mathrm{PhD}$ Thesis, Aberdeen, UK.

www.vermiculture.com, 2008 
Cord 2018, 34 (2) 